\title{
ANALISIS MUTU MIKROBIOLOGI DAN UJI VISKOSITAS FORMULA ENTERAL BERBASIS LABU KUNING (Curcubita moschata) DAN TELUR BEBEK
}

\author{
Lingga Edytias Pratiwi, Etika Ratna Noer ${ }^{*}$
}

Program Studi Ilmu Gizi Fakultas Kedokteran Universitas Diponegoro

Jl.Dr.Sutomo No.18, Semarang, Telp (024) 8453708, Email : gizifk@undip.ac.id

\begin{abstract}
Background: Enteral formula or liquid diet is one way to fulfill the nutrient especially for severely malnourished children. Enteral formula traditionally produced very vulnerable contaminated by microorganism if it not handled properly and correctly. Retention time will affect the number of microorganisms and quality of enteral formula itself. Objective: This study aims to analyze microbiology and viscosity of the enteral formula from pumpkin (Curcubita moschata) and duck egg based.

Methods: This study is a completely randomized design with a factor that is storage time of enteral formula to the value of TPC and Salmonella sp with 3 variations in treatment that formula stored for 1 hour, 2 hours and 3 hours at room temperature enclosed, and done with three repetition. Data were analyzed using One Way Anova test for viscosity and Repeated Anova to test the TPC with $95 \%$ degree for confidence.

Results: In the enteral formulas viscosity test showed a difference in level of viscosity with various concentrations of duck eggs, but it didn't significantly effect on viscosity ( $p>0,05)$. Long storage of enteral formulas is not significantly effect on the TPC. The value of TPC in shelf life is still in the normal range that is $0.19 \times 10^{4} \mathrm{cfu} / \mathrm{ml}$. While the shelf life of $\geq 2$ hours exceed the maximum limit and unqualified. To test identification of Salmonella was not found at all Salmonella sp and already qualified of SNI.

Conclusion: There are differences in level of viscosity with various concentrations of duck eggs, but did not significantly affect on the viscosity of enteral formulas. The longer storage of enteral formula will decrease the quality of enteral formula itself. There is no Salmonella sp on the enteral formula products and already qualified of SNI.

Keyword: Enteral formula; microbiological quality; viscosity
\end{abstract}

\section{ABSTRAK}

Latar Belakang: Formula enteral atau diet cair merupakan salah satu cara untuk memenuhi kebutuhan zat gizi khususnya bagi anak penderita gizi buruk. Formula enteral yang diproduksi secara tradisional sangat rentan tercemar oleh mikroorganisme bila tidak ditangani secara tepat dan benar. Lamanya waktu penyimpanan akan mempengaruhi kualitas formula enteral itu sendiri.

Tujuan: Penelitian ini bertujuan untuk menganalisis mikrobiologi dan uji viskositas dari formula enteral berbasis labu kuning dan telur bebek.

Metode: Penelitian ini merupakan penelitian eksperimental dengan rancangan acak lengkap satu faktor yaitu lama penyimpanan formula enteral terhadap nilai TPC dan Salmonella sp dengan 3 variasi perlakuan, yaitu formula yang disimpan selama 1 jam, 2 jam dan 3 jam di dalam suhu ruangan tertutup, dan dilakukan dengan tiga kali pengulangan. Data dianalisis menggunakan uji One Way ANOVA untuk uji Viskositas dan Repeated ANOVA untuk uji TPC dengan derajat kepercayaan $95 \%$.

Hasil: Pada uji viskositas formula enteral menunjukkan adanya perbedaan tingkat kekentalan dengan berbagai variasi konsentrasi telur bebek, namun berpengaruh tidak nyata terhadap viskositas $(p>0,05)$. Lama penyimpanan formula enteral berpengaruh tidak nyata terhadap TPC. Nilai TPC pada umur simpan masih dalam batas normal yaitu $0.19 \times 10^{4} \mathrm{cfu} / \mathrm{ml}$. Sedangkan umur simpan $\geq 2$ jam melebihi batas maksimal dan tidak memenuhi syarat. Untuk uji Identifikasi Salmonella tidak ditemukan sama sekali bakteri Salmonella sp dan sudah memenuhi syarat SNI.

Simpulan: Terdapat perbedaan tingkat kekentalan dengan berbagai konsentrasi telur bebek namun tidak berpengaruh nyata terhadap viskositas formula enteral. Semakin lama penyimpanan formula enteral maka akan semakin menurun kualitas formula enteral itu sendiri. Tidak terdapat bakteri Salmonella sp pada produk formula enteral dan sudah memenuhi syarat SNI.

Kata kunci: Formula enteral; mutu mikrobiologi; viskositas

\section{PENDAHULUAN}

Saat ini pemberian zat gizi pada anak gizi buruk merupakan faktor penting dalam mendukung proses penyembuhan dan pemulihan. Tujuannya adalah menjamin proses metabolisme tubuh secara optimal, meningkatkan kualitas hidup, mencegah keparahan malnutrisi serta menurunkan angka morbiditas dan mortalitas. ${ }^{1}$ Cara untuk mengatasi masalah gizi buruk atau gizi kurang adalah dengan memberikan dukungan zat gizi yang adekuat, tinggi protein dan energi serta cukup vitamin-mineral guna mencapai status gizi yang optimal. ${ }^{2}$

\footnotetext{
${ }^{*}$ Penulis Penanggungjawab
} 
Dukungan zat gizi dengan pemberian formula enteral atau diet cair merupakan salah satu metode pemenuhan gizi melalui saluran pencernaan, baik melalui mulut ataupun dengan bantuan alat (tube). Formula enteral mempunyai keunggulan lebih ekonomis, mudah dalam pembuatannya, mudah dicerna oleh anak-anak serta tinggi energi. ${ }^{3}$ Namun, makanan enteral khususnya yang dibuat secara tradisonal harus memperhatikan faktor higienitas dari penyiapan sampai penyajian sesuai standar baku. Hal ini dikarenakan formula enteral merupakan makanan cair yang sangat ideal bagi pertumbuhan mikroorganisme yang berasal dari komposisi bahan, persiapan selama produksi dan transportasi, ataupun berasal dari rumah sakit itu sendiri. ${ }^{4}$ Maka dari itu perlu dilakukan uji mikrobiologi untuk melihat tingkat keamanan dari jumlah mikroorganisme, karena mikroorganisme yang mencemari formula enteral dapat menyebabkan kerusakan dan mempengaruhi kualitas serta keamanan dari formula enteral itu sendiri bila tidak ditangani secara tepat dan benar. Kerusakan formula enteral menyebabkan makanan tersebut tidak aman untuk dikonsumsi jika sudah tercemar. ${ }^{5}$ Oleh sebab itu formula enteral sebaiknya dikonsumsi segera setelah dimasak karena bila dibiarkan lama dan dalam suhu ruangan lebih dari 3 jam akan mempengaruhi jumlah mikroorganisme dan kualitas dari formula enteral itu sendiri. ${ }^{4}$

Pada penelitian formula enteral ini menggunakan bahan pangan lokal yang mempunyai kandungan energi tinggi dan zat gizi lengkap, mudah didapat serta bersumber pada bahan pangan lokal. Salah satu bahan pangan lokal yang dapat dijadikan sebagai alternatif dalam pembuatan formula enteral adalah labu kuning dan telur bebek. Labu kuning merupakan jenis sayuran yang mudah didapat dan memiliki sumber zat gizi potensial, yang mana di dalam labu kuning kaya akan betakaroten dan antioksidan. ${ }^{6}$ Telur bebek jarang digunakan dalam pembuatan formula enteral, namun banyak sekali keunggulan yang terkandung didalamnya. Telur bebek memiliki protein tertinggi sebesar $80 \%$ dibandingkan dengan telur unggas lainnya, juga kaya akan antioksidan dan omega-3 di dalam kuning telurnya, sehingga cocok untuk pemenuhan zat gizi bagi anak yang mengalami kondisi gizi buruk atau gizi kurang. ${ }^{7,8}$ Selain itu digunakan juga susu kedelai sebagai subtitusi dari susu sapi dengan tujuan untuk menghindari atau mengurangi kejadian diare pada anak yang rentan terhadap susu sumber hewani.

Dari bahan - bahan yang digunakan dalam pembuatan formula enteral, dapat diketahui bahwa kandungan formula ini tinggi akan kandungan zat gizinya, dimana mikroorganisme menggunakan zat gizi tersebut untuk tumbuh dan berkembang biak dan merusak kualitas dari formula enteral itu sendiri. Selain itu bahan-bahan yang digunakan merupakan bahan makanan yang mudah rusak (perishable). Oleh sebab itu sangat diperlukan adanya uji mikrobiologi pada formula enteral untuk menentukan mutu dan daya tahan serta mendeteksi adanya mikroba pathogen yang dapat mengakibatkan penyakit ataupun keracunan. Tidak hanya uji mikrobiologi, uji viskositas pun perlu dilakukan dengan tujuan untuk menunjukkan kualitas fisik dari formula enteral, karena viskositas merupakan karakteristik penting dari makanan cair dalam pengolahan makanan. Hal ini dilakukan untuk mengetahui produk enteral yang dibuat sesuai dengan batas normal, tidak terlalu encer ataupun terlalu kental.

Berdasarkan latar belakang diatas maka dilakukan penelitian mengenai analisis mutu mikrobiologi dan uji viskositas formula enteral berbasis labu kuning dan telur bebek, untuk mengkaji apakah formula yang dibuat dan diteliti sudah sesuai dengan standar yang ditetapkan untuk produk formula enteral.

\section{METODE}

Penelitian yang dilakukan merupakan penelitian bidang Ilmu Gizi dan Teknologi Pangan dengan konsentrasi pada Mikrobiologi Pangan yang dilaksanakan mulai bulan Juli 2014 di Balai Laboraturium Kesehatan Semarang dan Laboratorium Teknologi Pangan Jurusan Gizi Fakultas Ilmu Kesehatan Universitas Muhammadiyah Semarang.

Pembuatan formula enteral menggunakan bahan utama yaitu labu kuning dan telur bebek serta tambahan tempe dan susu kedelai. Sebelum dilakukan uji mikrobiologi, dilakukan terlebih dahulu uji kandungan zat gizi $(\mathrm{KH}$, protein, lemak, abu), betakaroten, serat kasar, organoleptik dan viskositas pada formula enteral. Dari ketiga formulasi enteral dengan perbedaan pada konsentrasi telur bebek yaitu 3\%(A1) sebesar $25 \mathrm{~g}$, $5 \%$ (A2) $50 \mathrm{~g}$ dan $8 \%$ (A3) $75 \mathrm{~g}$, didapatkan hasil terbaik yaitu formula enteral dengan konsentrai telur bebek 5\%. Formula yang terpilih dilanjutkan dengan uji mikrobiologi untuk dianalisis mutu mikrobiologinya meliputi TPC dan Salmonella sp.

Penelitian ini merupakan penelitian eksperimental dengan rancangan acak lengkap satu faktor yaitu variasi konsentrasi telur bebek terhadap viskositas, dan lama penyimpanan formula enteral terhadap nilai TPC dan Salmonella $s p$ dengan 3 variasi perlakuan yaitu formula yang disimpan 
selama 1 jam (T1), 2 jam (T2) dan 3 jam (T3) di dalam suhu ruangan tertutup. Pengujian formula enteral dilakukan dengan tiga kali pengulangan pada setiap perlakuan sehingga didapat 9 sampel yang akan dianalisis mikrobiologinya. Variabel bebas (independen) yang ditentukan dalam penelitian ini adalah variasi konsentrasi telur bebek dan lama penyimpanan pada formula enteral berbasis labu kuning dan telur bebek. Sedangkan variabel terikat (dependen) penelitian ini meliputi uji viskositas, serta nilai TPC dan Salmonella.

Total Plate Count (TPC) merupakan metoda pendugaan jumlah mikroorganisme secara keseluruhan (kapang, khamir, bakteri) dalam suatu bahan. Analisis TPC menggunakan media Plate Count Agar (PCA) dengan menanam satu gram sampel yang telah diencerkan ke dalam cawan petri, kemudian di inkubasi. Hasil hitung TPC berupa koloni $(\mathrm{cfu}) / \mathrm{ml}$. Sedangkan untuk bakteri
Salmonella sp, analisis menggunakan metode identifikasi bakteri Salmonella. Pada pengujian deteksi Salmonella menggunakan Buffered Pepton Water (BPW) sebagai media cair non selektif, Tetrationat Broth (TB) dan Bismuth sulfith Agar (BSA) sebagai media selektif untuk mengisolasi Salmonella. Untuk pengujian viskositas hasil hitung yang digunakan adalah centipoise (cP).

Data dianalisis menggunakan program komputer SPSS 16 for windows dan diuji statistik dengan One Way ANOVA untuk uji Viskositas dan Repeated ANOVA untuk uji TPC dengan derajat kepercayaan $95 \%$.

\section{HASIL}

Viskositas Formula Enteral

Hasil viskositas pada formula enteral dengan berbagai komposisi telur bebek dapat dilihat pada Tabel 1.

Tabel 1. Hasil Viskositas Formula Enteral dengan Perbedaan komposisi Telur Bebek

\begin{tabular}{ccccccc}
\hline \multirow{2}{*}{ No } & \multirow{5}{*}{ Perlakuan } & \multicolumn{3}{c}{ Hasil viskositas $(\mathrm{cP})$} & \multirow{2}{*}{ Rata - rata } & SD \\
\cline { 3 - 5 } & & $\mathrm{U} 1$ & $\mathrm{U} 2$ & $\mathrm{U} 3$ & \\
\hline 1 & A1 & 1333,77 & 1297,65 & 1372,21 & 1334,54 & 37,29 \\
2 & A2 & 1416,68 & 1440,69 & 1427,59 & 1428,32 & 12,02 \\
3 & A3 & 1521,20 & 1534,57 & 1598,25 & 1551,34 & 41,17 \\
\hline
\end{tabular}

Berdasarkan Tabel 1 diatas, hasil menunjukkan bahwa nilai viskositas pada formula enteral berbanding lurus dengan berbagai konsentrasi telur bebek, dimana semakin tinggi konsentrasi telur maka semakin tinggi pula nilai viskositasnya. Nilai viskositas tertinggi terdapat pada formula enteral dengan konsentrasi telur bebek $8 \%$ yaitu sebesar $1551,34 \mathrm{cP}$, sedangkan nilai viskositas terendah yaitu formula dengan konsentrasi telur bebek 3\% sebesar 1334,54 cP.

\section{Mutu Mikrobiologi}

Total Plate Count ( TPC)

Hasil jumlah TPC pada formula enteral berbasis labu kuning dan telur bebek konsentrasi $5 \%$ dengan berbagai umur simpan dapat dilihat pada Tabel 2.

Tabel 2. Hasil Analisis TPC pada Formula Enteral

\begin{tabular}{cc}
\hline Parameter & Total Plate Count $(\mathrm{TPC})$ \\
\hline T1 & $0.19 \times 10^{4} \pm 0.19 \times 10^{4}$ \\
T2 & $1.32 \times 10^{4} \pm 0.59 \times 10^{4}$ \\
T3 & $3.49 \times 10^{4} \pm 4.27 \times 10^{4}$ \\
& $\mathrm{p}=0,261$ \\
\hline
\end{tabular}

Hasil analisis Total Plate Count (TPC) menunjukkan nilai TPC pada formula enteral berbanding lurus dengan berbagai umur simpan, yaitu semakin lama penyimpanan maka jumlah TPC akan semakin meningkat. Pada umur simpan selama 1 jam (T1) jumlah TPC masih dalam batas normal sesuai dengan SNI 01-2332.3-2006 yaitu 1,0 x $10^{4}$ cfu/g. ${ }^{10}$ Nilai TPC tertinggi dari formula enteral berbasis labu kuning dan telur bebek yaitu sebesar $3.49 \times 10^{4} \mathrm{cfu} / \mathrm{ml}$. Berdasarkan batas cemaran mikrobiologi, formula enteral dengan umur simpan 2-3 jam tidak memenuhi syarat dikarenakan kedua umur simpan tersebut sudah melampaui batas maksimal. 
Berdasarkan pada Tabel 2 diatas, diketahui bahwa nilai TPC meningkat seiring dengan lamanya penyimpanan. Namun dari hasil analisis statistik diketahui bahwa lama penyimpanan formula enteral berbasis labu kuning dan telur bebek tidak berpengaruh nyata terhadap nilai TPC $(\mathrm{p}>0,05)$.

\section{Salmonella sp}

Hasil identifikasi bakteri Salmonella pada formula enteral berbasis labu kuning dan telur bebek konsentrasi $5 \%$ dengan berbagai variasi lama penyimpanan dapat dilihat pada Tabel 3.

Tabel 3. Hasil Identifikasi Salmonella pada Formula Enteral

\begin{tabular}{cc}
\hline Parameter & Salmonella sp \\
\hline $\mathrm{T} 1$ & Negatif \\
$\mathrm{T} 2$ & Negatif \\
$\mathrm{T} 3$ & Negatif \\
\hline
\end{tabular}

Berdasarkan hasil identifikasi bakteri Salmonella $s p$ pada produk formula enteral berbasis labu kuning dan telur bebek dengan berbagai umur simpan, tidak ditemukan adanya bakteri Salmonella $s p$ yang mencemari formula tersebut. Hal ini sudah sesuai berdasarkan SNI 01-2332.3-2006 yang mana batas cemaran bakteri Salmonella adalah negatif yaitu $0 \mathrm{cfu} / 25 \mathrm{~g}$. Ini menunjukkan bahwa rangkaian proses pembuatan formula enteral berbasis labu kuning dan telur bebek dari mulai persiapan, pengolahan bahan baku, proses pembuatan sampai dengan pengemasan sudah aman dari cemaran bakteri Salmonella sp.

\section{PEMBAHASAN}

\section{Viskositas Formula Enteral}

Viskositas merupakan karakteristik penting dari makanan cair dalam bidang pengolahan makanan. Viskositas pada makanan cair banyak mengalami perubahan selama proses pemanasan maupun pendinginan. Untuk semua jenis makanan cair, viskositas akan menurun dengan adanya peningkatan suhu. ${ }^{11}$

Berdasarkan hasil analisis penelitian menunjukkan bahwa nilai viskositas pada formula enteral berbanding lurus dengan berbagai konsentrasi telur bebek, diamana semakin tinggi konsentrasi telur bebek yang digunakan maka semakin meningkat pula viskositas. Namun berdasarkan hasil analisis statistik menunjukkan bahwa perbedaan konsentrasi telur bebek tidak berpengaruh nyata terhadap viskositas formula enteral yaitu $p>0,05$. Rata-rata viskositas formula enteral menunjukkan tidak ada pengaruh yang nyata pada perlakuan, hal ini diduga karena pengaruh telur bebek dengan tingkat konsentrasi berbeda mempunyai efektivitas yang sama besar dalam pembentukan viskositas.

Berdasarkan tabel viskositas nilai absolut untuk makanan bayi adalah sebesar 1400 centipose (cP) , atau merujuk pada tekstur milk whey dengan tingkat kekentalan yaitu sebesar 800-1500 cP. ${ }^{9}$ Hal ini menunjukkan bahwa kekentalan untuk formula enteral labu kuning yang dibuat masih sesuai pada batas normal, tidak terlalu kental atau encer, serta formula yang paling mendekati adalah formula dengan konsentrasi telur bebek 5\% (50 g) sebesar $1428,32 \mathrm{cP}$

Telur bebek mengandung tinggi protein dan juga lemak sehingga dapat mengentalkan produk formula enteral. Hal ini sesuai dengan pernyataan Sughita dan Djalil yang menyatakan bahwa faktor yang mempengaruhi kekentalan adalah konsentrasi dan keadaan lemak, serta konsentrasi dan keadaan protein. Tingginya kadar protein dapat meningkatkan kekentalan. ${ }^{12}$ Faktor lain yang dapat mempengaruhi viskositas yaitu suhu, konsentrasi cairan, tekanan, dan berat molekul. ${ }^{13}$ Viskositas dan suhu memiliki perbandingan terbalik dimana semakin tinggi suhu, maka viskositas dari produk tersebut akan semakin rendah. Semakin besar konsentrasi bahan padatan dalam suatu produk maka viskositasnya semakin kecil. Viskositas akan meningkat dengan adanya kenaikan tekanan dan akan meningkat dengan naiknya berat molekul. ${ }^{13,14}$

Dari formula enteral yang diolah, bahan yang digunakan selain telur bebek juga terdapat tepung beras yang dapat mempengaruhi viskositas produk. Sebelum melalui proses pemanasan, konsistensi dari formula enteral yang diolah masih encer, namun setelah dipanaskan selama 30 menit dengan api kecil konsistensii berubah menjadi kental. Hal ini dikarenakan tepung beras memerlukan waktu pemasakan yang cukup lama untuk memberikan kekentalan pada produk. ${ }^{15}$

Formula enteral dengan tekstur cair hingga kental sangat membantu pasien khususnya untuk anak penderita gizi buruk yang kebanyakan mengalami gangguan dalam mengunyah, menelan dan juga mencerna. Selain itu, pemberian makanan enteral juga dapat menjaga agar fungsi 
gastrointestinal bekerja secara fisiologis. ${ }^{16}$ Sebuah penelitian menyatakan bahwa pemberian nutrisi enteral pada pasien gizi buruk terbukti memberikan dampak terhadap outcome yang positif, dimana pertumbuhan sel epitel intestinal, aktivitas enzim brush border, dan motilitas akan meningkat. ${ }^{17}$

\section{Mutu Mikrobiologi}

\section{Total Plate Count ( TPC)}

Total Plate Count (TPC) atau yang lebih dikenal dengan istilah Angka Lempeng Total merupakan perhitungan total mikroorganisme baik kapang, khamir, maupun koloni bakteri secara keseluruhan dalam satu bahan. ${ }^{10}$ Metode ini dapat memberikan gambaran bahan makanan secara keseluruhan, sehingga bila dalam makanan jumlah TPC tinggi maka kualitas dari makanan tersebut sangat rendah dan tidak layak untuk dikonsumsi.

Hasil pemeriksaan laboraturium pada formula enteral berbasis labu kuning dan telur bebek, menunjukkan bahwa nilai TPC tertinggi terdapat pada lama penyimpanan 3 jam yaitu sebesar $3.49 \times 10^{4} \mathrm{cfu} / \mathrm{ml}$, namun dalam masa simpan 2 jam, jumlah TPC sudah melebihi batas maksimal persyaratan formula khusus anak yaitu $1,0 \times 10^{4}$ cfu/gram. Hal ini menunjukkan bahwa sampel formula enteral yang digunakan sudah tidak layak untuk dikonsumsi bila melebihi waktu 1 jam, dikarenakan sudah melebihi batas maksimum cemaran mikroba. Dalam sebuah artikel ilmiah mengatakan bahwa produk makanan enteral rumahan (homemade tube feeding) tidak dapat dikonsumsi lebih dari dua jam bila tidak disimpan di dalam kulkas, sehingga tidak aman bila dikonsumsi. Formula akan awet hingga mencapai empat jam bila disimpan di dalam ruang pendingin. ${ }^{18}$ Meskipun terdapat perbedaan jumlah TPC dengan lama penyimpanan formula enteral, namun pada hasil analisis statistik menunjukkan bahwa variasi lama penyimpanan formula enteral terhadap nilai TPC tidak berpengaruh nyata atau tidak signifikan $(\mathrm{p}>0,05)$.

Tingginya nilai TPC pada formula enteral dapat dipengaruhi oleh beberapa faktor diantaranya bahan-bahan yang digunakan kaya akan zat gizi yang merupakan media tumbuh dan berkembang yang baik bagi mikroorganisme. Semakin lama penyimpanan produk makanan maka akan semakin banyak zat gizi yang digunakan oleh mikroorganisme dan semakin menurun pula kualitas zat gizi formula enteral. ${ }^{19}$ Faktor lain yang mempengaruhi pertumbuhan mikroorganisme adalah tingginya aktivitas air yang terdapat pada formula enteral sehingga mikroorganisme tersebut semakin tumbuh dan berkembang. aktivitas air (Aw) merupakan jumlah air bebas yang tersedia dan dapat digunakan untuk pertumbuhan mikroorganisme dalam bahan makanan, dimana setiap mikroorganisme yang berbeda membutuhkan jumlah air yang berbeda untuk pertumbuhannya. Pada Aw yang rendah, mikroorganisme akan mati karena sel-sel pada mikroorganisme akan berdifusi keluar akibat terjadinya proses kesetimbangan osmotik. ${ }^{20}$ Selain itu, adanya kontaminasi mikroba mungkin juga karena kesalahan penguji atau peralatan pengujian yang kurang bersih. Oleh karena itu perlu dilakukan pengujian ulang dengan personal yang berbeda dari personal yang pertama. ${ }^{21}$

\section{Salmonella sp}

Salmonella $s p$ merupakan salah satu bakteri penyebab utama dari penyakit yang disebarkan melalui makanan (foodborne disease) dan sering digunakan sebagai indikator baik buruk atau aman tidaknya makanan atau minuman. Bakteri ini bukan indikator sanitasi, melainkan indikator keamanan pangan. Artinya, karena semua serotype Salmonella yang diketahui bersifat patogen sehingga adanya bakteri ini dalam makanan dianggap membahayakan kesehatan. ${ }^{22}$

Pada pemeriksaan laboratorium dalam penelitian ini tidak menunjukkan adanya hasil positif cemaran bakteri Salmonella sp, dan juga belum terdapat satupun laporan terjadinya gangguan kesehatan akibat mengkonsumsi formula enteral. Namun, masih ada kemungkinan untuk terjadinya kontaminasi dalam proses pengadaan bahan baku, pengolahan hingga penyimpanan serta pada penggunaan air dan alat masak.

Hasil pemeriksaan yang positif Salmonella $s p$ memang jarang ditemukan karena potensi penyebaran bakteri ini memang lebih rendah dibandingkan dengan bakteri pathogen lain seperti E.coli. ${ }^{23}$ Kemungkinan lain penyebab tidak adanya cemaran Salmonella $s p$ adalah saat pemasakan formula enteral yang dimasak hingga mendidih, yang dapat mencapai suhu hingga $70^{\circ} \mathrm{C}$. Pada suhu ini Salmonella $s p$ tidak mampu untuk bertahan hidup. Batas temperatur untuk pertumbuhan Salmonella $s p$ berkisar antara $5,2-46,2^{\circ} \mathrm{C}$ dengan suhu optimal $35-43^{\circ} \mathrm{C}$. Ketahanan Salmonella $s p$ terhadap panas tergantung dari $\mathrm{pH}$ dan aktivitas air pada makanan. Bakteri dapat tumbuh dengan baik pada rentang $\mathrm{pH} 4-8$. Ketahanan panas Salmonella $s p$ akan meningkat seiring dengan penurunan aktifitas air pada makanan. ${ }^{24}$ Menurut sebuah penelitian, bakteri bisa tampak dengan aktivitas air yang rendah, namun tidak dapat tumbuh dan berkembang. ${ }^{25}$

Pada anak-anak yang sedang sakit khususnya penderita gizi buruk memiliki status imunitas yang sangat rendah, sehingga sangat 
rentan terinfeksi oleh kuman dan bakteri pathogen seperti Salmonella sp. Untuk itu dalam proses pemilihan bahan makanan dan pengolahannya pun harus sangat hati-hati dan harus mengedepankan higienitas dan sanitasi.

\section{SIMPULAN}

Berdasarkan hasil dan pembahasan dapat ditarik beberapa kesimpuan sebagai berikut:

1. Hasil uji Viskositas pada formula enteral berbasis labu kuning dan telur bebek menunjukkan adanya perbedaan tingkat kekentalan dengan berbagai variasi konsentrasi telur bebek, namun berpengaruh tidak nyata terhadap viskositas formula enteral $(p>0,05)$.

2. Pada formula enteral berbasis labu kuning dan telur bebek, jumlah Total Plate Count (TPC) dengan umur simpan 1 jam adalah $0.19 \times 10^{4}$ $\mathrm{cfu} / \mathrm{ml}$, sedangkan pada penyimpanan 2-3 jam formula enteral sudah tidak layak untuk dikonsumsi karena jumlah TPC sudah melebihi batas cemaran mikroba berdasarkan SNI 012332.3-2006 yaitu $1,0 \times 10^{4} \mathrm{cfu} / \mathrm{ml}$. Terdapat perbedaan lama penyimpanan namun berpengaruh tidak nyata terhadap jumlah TPC pada formula enteral $(p>0,05)$.

3. Hasil penelitian tidak menunjukkan adanya kontaminasi Salmonella sp pada formula enteral berbasis labu kuning dan telur bebek. Hal ini menunjukkan bahwa formula enteral yang dibuat sudah sesuai syarat dan bebas dari cemaran bakteri pathogen.

\section{SARAN}

1. Diperlukan penelitian lanjutan dengan mengembangkan penambahan bahan pangan alami pada produk formula enteral yang dapat menghambat pertumbuhan mikroorganisme agar dapat bertahan lama.

2. Formula enteral sebaiknya dikonsumsi setelah dimasak karena bila disimpan terlalu lama dan lebih dari 2 jam pada suhu ruangan dapat menurunkan kualitas formula serta tidak layak untuk dikonsumsi.

3. Agar formula enteral dapat bertahan hingga 4 jam, sebaiknya disimpan dalam ruang pendingin atau refrigerator.

\section{DAFTAR PUSTAKA}

1. Diah Krisnansari. Nutrisi dan Gizi Buruk. Mandala of Health. Volume 4, No. 1. Purwokerto: Universitas Jendral Soedirman; 2010.

2. Judarwanto, Widodo. Penanganan Terkini Kurang Energi Protein (KEP) pada anak. Jakarta. Children Grow Up Clinic Indonesia; 2012.
3. Setyobudi, Astutik P, dan Bachyar B. Pengaruh PMT-Pemulihan dengan Formula WHO terhadap Status Gizi Anak Balita KEP di Kota Malang. Malang. Media Gizi \& Keluarga; 2005.

4. Hapsari, Hanna Triana P. Pengendalian Mutu Dalam Proses Pembuatan Makanan Enteral Di Rumah Sakit Dustira Cimahi.dalam Karya Tulis Ilmiah. Bogor: Institut Pertanian Bogor; 2012.

5. De Leeuw I H and Vandewoude M F. Bacterial Contamination of Enteral Diets. Division of Clinical Nutrition, University of Antwerp, Belgium. Gut, 27, SI, 56-57.

6. Zaitun. Pemanfaatan Buah Labu Kuning sebagai Bahan Dasar dalam Pengolahan Makanan dan Untuk Mencegah Berbagai Jenis Penyakit. Medan.

7. Miguel Marta, Rosina Lopez, Mercedes R. Comparative Study of Egg Whte Proteins from Different Species by Chromatographic and Electrophoretic Methods. Eur Food Res Technol; 221:542-546. 2005.

8. Pahari Priyanka, Mandal S.K, Sandip Ghosh, and Maity C.R. Nutrient Present in Easily Available Hen's and Duck's Eggs in The Markets of West Bengal, India. An Online International Journal Available at http://www.cibtech.org/jls.htm 2011 Vol. 1 (4). India.

9. Viscosity Charts and Conversion Table. Additional Product Available at www.bascousa.com.

10. Penentuan Total Plate Count (angka Lempeng Total): SNI 01-2332.3-2006.

11. Fellow, P. Food Processing Technology Principles and Practise. CRC Press, New York: 2000.

12. Sughita dan Djalil. Susu: Pengolahan dan Teknologinya. Teknologi Hasil Ternak, Fakultas Peternakan: Universitas Andalas; Padang.

13. Malcolm Bourne. Food Texture and Viscosity: Concept and Measurement. Second Edition. Page:78-81. Available from: http://www.academicpress.com. 2002.

14. Budi, Eli Santoso. Pengaruh Penambahan Berbagai Jenis dan Konsentrasi Susu Terhadap Sifat Sensoris dan Sifat Fisikokimia Puree Labu Kuning. Jurnal Teknosains Pangan Vol 2 No 3. Available online at: http://www.ilmupangan.fp.uns.ac.id. 2013.

15. Imanningsih, Nelis. Profil Gelatinisasi Beberapa Formula Tepun-tepungan. Penel Gizi Makan, 35(1): 13-22. 2012.

16. Rusli Damayanti, Endang Dewi, Maria M, dan Sri Soedarjati. Buku Ajar: Nutrisi Pediatrik dan Penyakit Metabolik, Jilid I ; hal.51. Jakarta: IDAI. 2012.

17. Heylan DK, Cahill EM, Dhaliwal R, Sun X, Day AG, and McClave SA. Impact of Enteral Feeding Protocols on Enteral Nutrition Delivery: Results of a Multicenter Observational Study. JPEN; 34:67584. 2010.

18. Seattle Children's. Homemade Blenderized Tube Feeding. Patient and Family Education. Washington. 2013. 
19. Antara, S, I.B.W. Gunam. Dunia Mikroba (Bahaya Mikrobiologis pada Makanan). Denpasar : Pusat Kajian Keamanan Pangan Universitas Udayana. 2002.

20. Rockland, L.B Beuchat, L.R. Water Activity Theory and Application to Food ( $2^{\text {nd }}$ edition). New York: Marcell Dekker. The Science Teacher 51 (7): 29-31.

21. Agung, Sri Fitria Kusuma. Uji Biokimia Bakteri. Dalam Karya Tulis Ilmiah. Fakultas Farmasi: Universitas Padjajaran; Bandung. 2009

22. James M. J, Martin J.L, David A.G. Modern Food Microbiology. Food Science Text Series. Springer: 2005.

23. Oscar, G., G. Duarte, J. Bai, and N. Elizabeth. Detection of Escherichia coli, Salmonella sp., Shigella sp., Yersinia enterolitica, Vibrio cholerae, and Camphylobacter sp. Enteropathogens by 3 reaction multiplex polymerase chain reaction. Diagnostic Microbiol. Infectious Dis. 63: $1 \square 9$. 2009.

24. Shachar D, Yaron S Heat tolerance of Salmonella enterica serovars Agona, Enteritidis, and Typhimurium in peanut butter. Journal of Food Protection 69(11):2687-2691. 2006

25. Shaw, Angela. Salmonella: Create The Most Undesirable Environtment. Ames, IA: Iowa State University. 2013. 